\title{
Purification and properties of two lactose hydrolases from Trichosporon cutaneum
}

\author{
Mark West, George W. Emerson and Patrick A. Sullivan* \\ Department of Biochemistry, University of Otago, PO Box 56, Dunedin, New Zealand
}

(Received 10 January 1990; revised 28 March 1990; accepted 4 April 1990)

\begin{abstract}
Two enzymes that hydrolysed lactose were purified essentially to homogeneity from cell extracts of the oleaginous yeast Trichosporon cutaneum. One enzyme of $M_{\mathrm{r}} 120000$ had properties typical of a $\beta$-galactosidase (EC 3.2.1.23). It hydrolysed lactose, lactulose and nitrophenyl- $\beta$-D-galactosides. The enzyme required $\mathrm{K}^{+}$or $\mathbf{R b}^{+}$ for activity, and other monovalent cations tested were not effective. Enzyme activity was abolished by EDTA and stimulated by $\mathrm{Mg}^{2+}, \mathrm{Mn}^{2+}$ and $\mathrm{Ca}^{2+}$. The $\beta$-galactosidase was induced by lactose, galactose, lactulose and lactobionic acid. The other enzyme, a $\beta$-glycosidase (EC 3.2.1.21) of $M_{\mathrm{r}} 52000$ showed no ionic requirements and it hydrolysed lactose, nitrophenyl- $\beta$-D-galactosides, 4-nitrophenyl- $\beta$-D-glucoside, cellobiose, laminaribiose, laminaritriose and sophorose, but not gentiobiose, 4-nitrophenyl- $\beta$-D-mannoside or sucrose. This enzyme was induced by lactose, galactose and lactulose, and also by cellobiose.
\end{abstract}

\section{Introduction}

Lactose hydrolysis in most micro-organisms is attributed to a $\beta$-galactosidase which hydrolyses lactose and other $\beta$-galactosides, but not $\beta$-glucosides. Typical $\beta$-galactosidases have a multi-subunit structure and metal ion requirements similar to the enzyme from Escherichia coli (Wallenfels \& Weil, 1972). Few yeasts grow on lactose, and Barnett (1981) concluded that of 439 yeasts surveyed, only 51 could utilize the disaccharide. Lactose hydrolases have been purified from several yeasts, including Kluyveromyces lactis (Dickson et al., 1979) and Saccharomyces fragilis (Uwajima et al., 1972), and these are similar to the $E$. coli $\beta$-galactosidase. In this paper we report the purification and properties of two lactosehydrolysing enzymes from the oleaginous yeast Trichosporon cutaneum.

\section{Methods}

Organism, growth conditions and media. Trichosporon cutaneum was originally isolated from dairy factory floor drains by Moon et al. (1978). Our isolate, obtained from the American Type Culture Collection as Apiotrichum curvatum ATCC 20509, was provided by J. R. Davies, Industrial Processing Division, DSIR, Petone, New Zealand. It was subsequently identified by the National Collection of Yeast Cultures,

Abbreviations: ONPGal, 2-nitrophenyl $\beta$-D-galactopyranoside; PNPGal, 4-nitrophenyl $\beta$-D-galactopyranoside; PNPGlu, 4-nitrophenyl $\beta$-D-glucopyranoside.
Norwich, UK as a strain of $T$. cutaneum. The organism was maintained on $3.4 \%(w / v)$ malt extract agar slopes (Difco). Synthetic medium contained (w/v) $5 \%$ lactose, $0.1 \%$ casein acid hydrolysate, $0.15 \%$ yeast extract, trace elements and salts except $\left(\mathrm{NH}_{4}\right)_{2} \mathrm{SO}_{4}$ (Wickerham, 1946). Synthetic medium (10 1), in a 101 New Brunswick Microgen fermenter was inoculated with $100 \mathrm{ml}$ of an $18 \mathrm{~h}$ culture, and grown at $28^{\circ} \mathrm{C}$ with $101 \mathrm{~min}^{-1}$ aeration and 400 r.p.m. agitation to an $\mathrm{OD}_{600}$ of approximately $5 \cdot 0$. Cells were harvested in a Sharples continuous flow centrifuge.

Enzyme purification. The cell paste $(150-300 \mathrm{~g}$ wet weight) was resuspended to a cream consistency in extraction buffer ( $8 \mathrm{~mm}$-sodium phosphate, pH 7, containing $1 \mathrm{mM}$-EDTA, $1 \mathrm{~mm}$-dithiothreitol and $10 \%, \mathrm{v} / \mathrm{v}$, glycerol), and passed once through a French Press at 20000 p.s.i. $(=138 \mathrm{~Pa})$. To reduce viscosity, the homogenate was sonicated $(10 \times 2 \mathrm{~s})$ with a Branson Sonifier. This suspension was diluted to $600 \mathrm{ml}$ with extraction buffer, and centrifuged at $35000 \mathrm{~g}$ for $60 \mathrm{~min}$. It was not possible to recover all of the cell-free extract from the loose cell debris. The cell-free extract was mixed with $140 \mathrm{ml}$ (bed volume) of DEAE-Sepharose CL-6B (Pharmacia) equilibrated in extraction buffer, and the suspension was stirred for $1-2 \mathrm{~h}$. The resin was recovered by filtration, resuspended in an equal volume of buffer, and stirred for a further 1-2 h. Finally, the resin was washed for $30 \mathrm{~min}$ with extraction buffer containing $0 \cdot 1 \mathrm{M}-\mathrm{NaCl}$, filtered, resuspended in the buffered $\mathrm{NaCl}$ and transferred to a $30 \times 2.5 \mathrm{~cm}$ column. This was washed with extraction buffer plus $0 \cdot 1 \mathrm{M}-\mathrm{NaCl}$ until the $A_{280}$ was zero. Protein was then eluted with $360 \mathrm{ml}$ of a linear $0 \cdot 1-0.25 \mathrm{M}-\mathrm{NaCl}$ gradient in extraction buffer at $15 \mathrm{ml} \mathrm{h}^{-1}$. Two peaks which hydrolysed 4-nitrophenyl $\beta$-D-galactopyranoside (PNPGal) were separately pooled. The first, a $\beta$-glycosidase was concentrated by ultrafiltration with a $50000 M_{\mathrm{r}}$ cut-off membrane, and the second a $\beta$-galactosidase was concentrated with a $100000 M_{\mathrm{r}}$ cut-off membrane. The concentrates were diluted fivefold in buffer $\mathrm{A}$ ( $8 \mathrm{mM}$-sodium phosphate, $\mathrm{pH} 7$, containing $1 \mathrm{~mm}$-EDTA, $2 \mathrm{~mm}$-dithiothreitol and $5 \%$, v/v, glycerol), and concentrated again by ultrafiltration. Each enzyme preparation 
was loaded onto a Fast-Flow DEAE-Sepharose (Pharmacia) column $(300 \mathrm{~mm} \times 10 \mathrm{~mm})$ equilibrated in buffer $A$ containing $0 \cdot 1 \mathrm{M}-\mathrm{NaCl}$. The $\beta$-glycosidase was eluted with a linear gradient $(180 \mathrm{ml})$ of $0 \cdot 1-0 \cdot 4 \mathrm{M}-\mathrm{NaCl}$ in buffer $\mathrm{A}$ and the $\beta$-galactosidase was eluted with a linear gradient $(180 \mathrm{ml})$ of $0.1-0.5 \mathrm{M}-\mathrm{NaCl}$ in buffer $\mathrm{A}$. Each enzyme fraction was again concentrated by ultrafiltration. The $\beta$-glycosidase preparation was applied to a Mono Q (HR 5/5) column (Pharmacia) equilibrated with buffer $A$ plus $0.1 \mathrm{M}-\mathrm{NaCl}$. It was eluted with a linear gradient $(26 \mathrm{ml})$ of $0.1-0.4 \mathrm{M}-\mathrm{NaCl}$ in buffer $\mathrm{A}$. The $\beta$-galactosidase was treated in the same way. $\left(\mathrm{NH}_{4}\right)_{2} \mathrm{SO}_{4}(3.9 \mathrm{M})$ was added to the pooled fractions of each enzyme to a final concentration of $1.4 \mathrm{M}$. After centrifuging ( $2700 \mathrm{~g}$ for $5 \mathrm{~min}$ ) each preparation was applied to a Phenyl Superose (HR 5/5) column (Pharmacia) equilibrated with $1.4 \mathrm{M}-\left(\mathrm{NH}_{4}\right)_{2} \mathrm{SO}_{4}$ in buffer $\mathrm{A}$, and the column was washed until the $A_{280}$ returned to zero. For each enzyme preparation, protein was then eluted with a reverse linear gradient $(16 \mathrm{ml})$ of $1.4-0 \mathrm{M}-\left(\mathrm{NH}_{4}\right)_{2} \mathrm{SO}_{4}$ in buffer $\mathrm{A}$ and the active fractions were pooled. Finally, each enzyme preparation was applied to and eluted from a $600 \mathrm{~mm} \times 3.7 \mathrm{~mm}$ column of Superose 12 (Pharmacia) in buffer A at $0.3 \mathrm{ml} \mathrm{min}^{-1}$. The purified enzymes were stored at $4{ }^{\circ} \mathrm{C}$ in buffer $\mathrm{A}$.

Enzyme assays. $\beta$-Galactosidase (EC 3.2.1.23) was assayed at $37^{\circ} \mathrm{C}$ in a total volume of $1.2 \mathrm{ml}$ containing $20 \mathrm{~mm}$-potassium phosphate, $\mathrm{pH} 7 \cdot 0,0.1 \mathrm{~mm}-\mathrm{MgSO}_{4}$ and $2.2 \mathrm{~mm}-\mathrm{PNPGal}$. The reaction rate was constant and time allowed for colour to develop varied from 0.5 to $20 \mathrm{~min}$. The reaction was stopped by the addition of $0.5 \mathrm{ml}$ $1.0 \mathrm{M}-\mathrm{Na}_{2} \mathrm{CO}_{3}$, and absorbance was read at $420 \mathrm{~nm}$. $\beta$-Glycosidase (EC 3.2.1.21) activity was measured in the same way but the reaction mixture contained $20 \mathrm{~mm}$-potassium phosphate, $\mathrm{pH} 7 \cdot 0$, and 2.2 mM-4-nitrophenyl $\beta$-D-glucopyranoside (PNPGlu). One unit of each enzyme catalyses the production of $1 \mu \mathrm{mol}$ 4-nitrophenol $\mathrm{min}^{-1}$ (4-nitrophenol $\varepsilon=160001 \mathrm{~mol}^{-1} \mathrm{~cm}^{-1}$ ). For substrates other than the nitrophenyl derivatives, the assay conditions were as described above except that the total assay volume was $0.5 \mathrm{ml}$, the reactions were stopped by heating at $100^{\circ} \mathrm{C}$ for $1 \mathrm{~min}$, and glucose and fructose were measured as described below. Assays were done in duplicate with a reliability of $\pm 5 \%$.

Analytical methods. Protein was measured by the Lowry method after precipitation with trichloroacetic acid (Peterson, 1977), using bovine serum albumin as a standard. SDS-PAGE was done with $10 \%$ separating gels and 5\% stacking gels (Laemmli \& Favre, 1973) in a mini-gel apparatus (Matsudaira \& Burgess, 1978). Samples (1-20 $\mu$ ) were loaded and the gels were run at constant voltage $(150 \mathrm{~V})$ for approximately $90 \mathrm{~min}$. Carbonic anhydrase $\left(M_{\mathrm{r}} 29000\right)$, ovalbumin (45000), bovine serum albumin (66000), phosphorylase (97400) and $\beta$-galactosidase (116000) were used as $\boldsymbol{M}_{\mathrm{r}}$ markers. Gels were fixed for $2 \mathrm{~h}$ in $25 \%(\mathrm{v} / \mathrm{v})$ propan-2-ol containing $10 \%(\mathrm{v} / \mathrm{v})$ acetic acid. After washing in deionized water for at least $2 \mathrm{~h}$, the gels were silver-stained (Morrisey, 1981), and the staining reaction was stopped with $2 \mathrm{M}$-acetic acid. Glucose was assayed as described by Bruss \& Black (1978) using glucose oxidase (Sigma type V-S) and 2,2'-azino-bis(3-ethylbenzthiazoline-6-sulphonic acid) as the chromogen. Fructose was measured using the procedure of Sturgeon (1980).

Chemicals. The nitrophenyl substrates and protein standards were from Sigma. Laminari-biose, -triose, -tetraose and -pentose were from Seikagaku Kogyo (Tokyo).

\section{Results}

\section{Cellular location of the activity}

Preliminary experiments were done to determine the cellular location of the lactose hydrolase activity. No

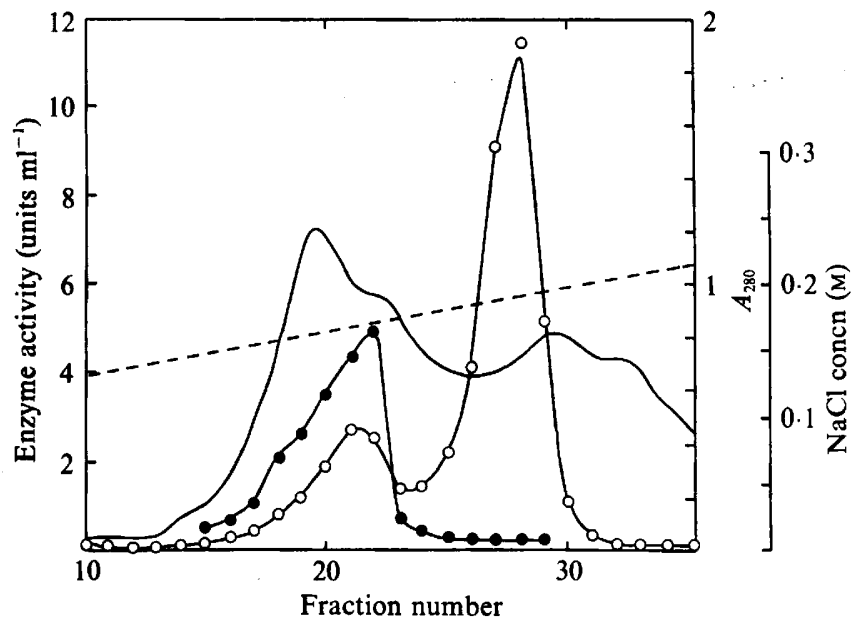

Fig. 1. DEAE-Sepharose chromatography. Cell-free extract was treated batchwise with DEAE-Sepharose, washed and the resin transferred to a column as described in Methods. Protein was eluted with a $\mathrm{NaCl}$ gradient (----). The eluate was monitored at $A_{280}(-)$. Fractions of $10 \mathrm{ml}$ were collected and enzyme activity measured with PNPGal (O) and PNPGlu (•).

activity was detected in the culture medium. Lactosegrown cells were treated with Novozyme 234, a cell wall lyticase, as described by Mörtberg \& Neujahr (1986). No activity was released, and the activity of spheroplast extracts was the same as that of cell-free extracts. From these observations we concluded that the lactose hydrolase activity was intracellular.

\section{Purification of the two enzymes}

Cells for the enzyme purification were harvested at an $\mathrm{OD}_{600}$ of 5.0 because of the relatively high enzyme activity and the low lipid content. Even so, it was necessary to decant the cell-free extract carefully to reduce the carry-over of the floating lipid and the soft pellet of cell debris. Preliminary experiments showed that the enzyme activity was bound tightly to DEAESepharose, and that the initial purification was most effective when the absorption was done in a batchwise method. The washed resin was transferred to a column, and the subsequent application of a shallow $\mathrm{NaCl}$ gradient resulted in the elution of two enzymes. The first, a $\beta$-glycosidase, hydrolysed both PNPGal and PNPGlu; the second, $\beta$-galactosidase, only PNPGal (Fig. 1). These two enzyme fractions were purified separately by ion exchange, hydrophobic and gel filtration chromatography. The pooled enzyme fractions were concentrated by ultrafiltration, the recoveries ranging from $\mathbf{5 0}$ to $100 \%$. The recovery of the $\beta$-glycosidase after the Mono Q step was usually greater than $50 \%$. Recoveries from Phenyl Superose chromatography [including the 
Table 1. Purification of $\beta$-glycosidase and $\beta$-galactosidase

\begin{tabular}{lcccc}
\hline \hline \multicolumn{1}{c}{ Treatment } & $\begin{array}{c}\text { Volume } \\
\text { (ml) }\end{array}$ & $\begin{array}{c}\text { Activity } \\
\text { (units) }\end{array}$ & $\begin{array}{c}\text { Protein } \\
(\mathrm{mg})\end{array}$ & $\begin{array}{c}\text { Specific activity } \\
\text { (units mg }\end{array}$ \\
\hline $\begin{array}{l}\boldsymbol{B} \text {-Glycosidase } \\
\text { Crude preparation }\end{array}$ & 262 & & & \\
After DEAE-Sepharose & 52 & 260 & 1600 & $0 \cdot 16$ \\
After Fast-Flow DEAE-Sepharose & 21 & 134 & 68 & $2 \cdot 0$ \\
After Mono Q & $4 \cdot 3$ & 124 & 25 & $5 \cdot 0$ \\
After Phenyl Superose & $1 \cdot 9$ & 20 & $3 \cdot 5$ & $5 \cdot 7$ \\
After gel filtration & $6 \cdot 4$ & 12 & $0 \cdot 7$ & 17 \\
$\beta$-Galactosidase & & 11 & $0 \cdot 45$ & 24 \\
Crude preparation & 262 & 260 & 1600 & \\
After DEAE-Sepharose & $41 \cdot 7$ & 210 & 46 & $0 \cdot 16$ \\
After Fast-Flow DEAE-Sepharose & $22 \cdot 0$ & 155 & 13 & $4 \cdot 6$ \\
After Mono Q & $5 \cdot 2$ & 72 & $2 \cdot 9$ & 12 \\
After Phenyl Superose & $2 \cdot 6$ & 41 & $0 \cdot 44$ & 25 \\
After gel filtration & $7 \cdot 7$ & 44 & $0 \cdot 34$ & 93 \\
\hline \hline
\end{tabular}

addition of $\left(\mathrm{NH}_{4}\right)_{2} \mathrm{SO}_{4}$ and centrifugation] ranged from 30 to $60 \%$ for both the $\beta$-galactosidase and $\beta$-glycosidase. Each enzyme eluted from this column was associated with one symmetrical peak. The overall purifications were 150 - and 810 -fold for the $\beta$-glycosidase and the $\beta$-galactosidase, respectively (Table 1).

\section{$M_{r}$ values of the two enzymes}

Both enzyme preparations were at least $90 \%$ pure as judged by SDS-PAGE and silver staining. The $M_{\mathrm{r}}$ values for the $\beta$-galactosidase and the $\beta$-glycosidase were 120000 and 52000 , respectively. The $\beta$-glycosidase eluted from the Superose 12 gel filtration column (in $100 \mathrm{~mm}$-sodium phosphate buffer, $\mathrm{pH} 7$, containing DTT, EDTA and glycerol at 2 and $1 \mathrm{~mm}$ and $10 \%, \mathrm{v} / \mathrm{v}$, respectively) had an apparent $M_{\mathrm{r}}$ of 59000 . With the same buffer system the $\beta$-galactosidase had an apparent $M_{\mathrm{r}}$ of 180000 , but with $8 \mathrm{mM}$ buffer or $8 \mathrm{mM}$ buffer containing $20 \mathrm{mM}-\mathrm{NaCl}$ the apparent $M_{\mathrm{r}}$ was 400000 . These data showed that the native $\beta$-glycosidase exists in the monomeric form, whereas the $\beta$-galactosidase is an oligomer. We suggest that the $\beta$-galactosidase species identified by gel filtration are dimeric and tetrameric forms. The native $E$. coli $\beta$-galactosidase is a tetramer with an apparent $M_{\mathrm{r}}$ of 540000 (Wallenfels \& Weil, 1972).

\section{Stability}

The enzyme activity in crude cell-free extracts prepared in $8 \mathrm{~mm}$-sodium phosphate buffer was not stable $(95 \%$ of the activity was lost after $11 \mathrm{~d}$ storage at $4{ }^{\circ} \mathrm{C}$ ) unless DTT, EDTA and glycerol were added to the preparations (Table 2). These reagents were therefore included in the buffer solutions used throughout the purifications. When the purified enzymes were stored under similar conditions, more than $90 \%$ of the activity was retained after 1 month.

The stability of each enzyme was also measured in dilute solutions stored for $7 \mathrm{~d}$ at $4{ }^{\circ} \mathrm{C}$ (Table 2). The $\beta$-galactosidase was most stable in potassium phosphate, pH 6 ( $16 \%$ loss of activity), and the $\beta$-glycosidase was most stable in the range $\mathrm{pH} 7$ to 9 in potassium phosphate or triethanolamine ( $\leqslant 16 \%$ loss of activity). At $37^{\circ} \mathrm{C}$ dilute solutions of the $\beta$-galactosidase specifically required $\mathrm{K}^{+}$for stability (Table 2 ).

\section{Properties of the two enzymes}

Both enzymes were optimally active at $37^{\circ} \mathrm{C}$ when tested over the range 25 to $45^{\circ} \mathrm{C}$. The $\beta$-glycosidase exhibited a broad $\mathrm{pH}$ optimum from $\mathrm{pH} 6$ to 7 , and the $\beta$-galactosidase had maximum activity in the $\mathrm{pH}$ range 6.5 to 7 .

Both enzymes were assayed at $\mathrm{pH} 7.0$ in the following range of $50 \mathrm{~mm}$-buffers: sodium phosphate, triethanolamine $/ \mathrm{HCl}, \mathrm{TES} / \mathrm{NH}_{4} \mathrm{OH}$ and Tris/ $\mathrm{HCl}$, supplemented with $200 \mathrm{mM}-\mathrm{KCl}$ and $10 \mathrm{mM}-\mathrm{MgSO}_{4}$ for the $\beta$-galactosidase. Compared with the activity under the standard assay conditions, the $\beta$-galactosidase was not markedly affected by any of the buffers. The $\beta$-glycosidase, however, was inhibited strongly by Tris ( $88 \%$ inhibition) and to a lesser extent by triethanolamine $(35 \%$ inhibition).

The $\beta$-glycosidase did not exhibit any requirement for metal ions, and it was fully active in 5 mM-EDTA. The $\beta$-galactosidase had an absolute requirement for a monovalent ion, and of those tested, only $\mathrm{K}^{+}$and $\mathbf{R b}^{+}$ activated the enzyme (Table 3). The enzyme also required a divalent cation. No activity was observed 
Table 2. Stability of the two enzymes

Expt 1. Samples of crude extract [9.6 $\mu \mathrm{mol}$ PNPGal hydrolysed $\left.\min ^{-1}(\mathrm{ml} \text { enzyme })^{-1}\right]$ in $8 \mathrm{mM}$-sodium phosphate buffer, $\mathrm{pH} 7 \cdot 0$, were incubated as indicated at $4{ }^{\circ} \mathrm{C}$ for $11 \mathrm{~d}$ and assayed for activity with PNPGal. Expt 2 . Purified $\beta$-galactosidase (130 units $\mathrm{mg}^{-1}, 4.4 \mu \mathrm{g} \mathrm{ml}^{-1}$ ) and $\beta$-glycosidase ( 24 units $\mathrm{mg}^{-1}, 7 \mu \mathrm{g} \mathrm{ml}^{-1}$ ) were stored for $7 \mathrm{~d}$ at $4{ }^{\circ} \mathrm{C}$ in $90 \mathrm{~mm}$ buffers as indicated. Expt 3 . Purified $\beta$-galactosidase (130 units $\mathrm{mg}^{-1}, 0.37 \mu \mathrm{g} \mathrm{ml}^{-1}$ ) was incubated for $10 \mathrm{~min}$ at $37^{\circ} \mathrm{C}$ as indicated. Results are expressed as percentage of activity remaining after the incubations.

\begin{tabular}{|c|c|c|}
\hline $\begin{array}{l}\text { Expt } 1 \\
\quad \text { Addition to crude extract }\end{array}$ & \multicolumn{2}{|c|}{$\begin{array}{c}\text { Total } \beta \text {-galactosidase } \\
\text { activity }(\%)\end{array}$} \\
\hline None & \multicolumn{2}{|r|}{5} \\
\hline $5 \mathrm{~mm}-\mathrm{DTT}$ & \multicolumn{2}{|r|}{18} \\
\hline $1 \mathrm{mM}-\mathrm{EDT} A$ & \multicolumn{2}{|r|}{25} \\
\hline $10 \%(\mathrm{v} / \mathrm{v})$ glycerol & \multirow{2}{*}{\multicolumn{2}{|c|}{$\begin{array}{l}11 \\
70\end{array}$}} \\
\hline DTT, EDTA and glycerol & & \\
\hline $\begin{array}{l}\text { Expt } 2 \\
\quad \text { Conditions }\end{array}$ & $\begin{array}{c}\beta \text {-Galactosidase } \\
\text { activity }(\%)\end{array}$ & $\begin{array}{c}\beta \text {-Glycosidase } \\
\text { activity }(\%)\end{array}$ \\
\hline Sodium acetate, $\mathrm{pH} 5 \cdot 0$ & 10 & 0 \\
\hline Sodium acetate, pH 6.0 & 64 & 50 \\
\hline Sodium phosphate, pH 6.0 & 84 & 75 \\
\hline Sodium phosphate, $\mathrm{pH} 7.0$ & 69 & 91 \\
\hline Sodium phosphate, $\mathrm{pH} 8.0$ & 31 & 91 \\
\hline Triethanolamine $/ \mathrm{HCl}, \mathrm{pH} 8.0$ & 9 & 94 \\
\hline Triethanolamine $/ \mathrm{HCl}, \mathrm{pH} 9.0$ & 0 & 84 \\
\hline $\begin{array}{l}\text { Expt } 3 \\
\quad \text { Conditions }\end{array}$ & $\begin{array}{c}\beta \text {-Galactosidase } \\
\text { activity }(\%)\end{array}$ & $\begin{array}{c}\beta \text {-Glycosidase } \\
\text { activity }(\%)\end{array}$ \\
\hline $\begin{array}{l}17 \text { mM-potassium phosphate, } \\
\text { pH } 7 \cdot 0\end{array}$ & 90 & ND \\
\hline $\begin{array}{l}17 \text { mM-sodium phosphate, } \\
\text { pH 7.0 }\end{array}$ & 5 & ND \\
\hline 17 mM-sodium phosphate, & & \\
\hline $\mathrm{pH} 7 \cdot 0$, plus $17 \mathrm{mM}-\mathrm{KCl}$ & 50 & ND \\
\hline
\end{tabular}

ND, Not determined.

when 5 mM-EDTA was included in the enzyme assay. When $\mathrm{Mg}^{2+}$ was omitted from the standard assay system, the enzyme showed $30-60 \%$ of the activity under the standard conditions. This may have been due to varying amounts of divalent ions in the preparations. Two other divalent cations, $\mathrm{Mn}^{2+}$ and $\mathrm{Ca}^{2+}$, also stimulated activity (Table 3), but to a lesser extent than $\mathrm{Mg}^{2+}$. $\quad \beta$-Mercaptoethanol $(300 \mathrm{mM})$, increased the $\beta$-galactosidase activity by $50 \%$. Wallenfels \& Weil (1972) suggested that a similar result with the $E$. coli $\beta$-galactosidase was due to the thiol reagent being a more efficient acceptor of the galactosyl moiety. $\beta$-Mercaptoethanol had no effect on the $\beta$-glycosidase activity.

Table 4 summarizes the kinetic constants $k_{\text {cat }}$ and $K_{\mathrm{m}}$ for the enzymes with lactose, PNPGal and 2-nitrophenyl $\beta$-D-galactopyranoside (ONPGal). Although the $k_{\text {cat }}$ of the $\beta$-galactosidase with lactose is eight times greater than that of the $\beta$-glycosidase $\left(400 \mathrm{~s}^{-1}\right.$ and $50 \mathrm{~s}^{-1}$,
Table 3. Effect of monovalent and divalent ions on $\beta$-galactosidase activity

The activity is expressed relative to the standard assays using (a) 0.0085 units and $(b) 0.052$ units of $\beta$-galactosidase. The results are means of duplicate determinations. For testing monovalent ions each assay contained $20 \mathrm{~mm}$-triethanolamine $/ \mathrm{HCl}$ buffer, $\mathrm{pH} 7 \cdot 0$, $0.1 \mathrm{mM}-\mathrm{MgSO}_{4}$, and $20 \mathrm{~mm}$ monovalent cation (the chloride salt except for lithium which was the acetate salt). For testing divalent ions each assay contained $17 \mathrm{~mm}$-potassium phosphate, $\mathrm{pH} 7 \cdot 0$, and $0.01 \mathrm{~mm}$ divalent cation (the chloride salt except for $\mathrm{Mg}^{2+}$ and $\mathrm{Cu}^{2+}$ which were the sulphate salts).

\begin{tabular}{lclc}
\hline \hline $\begin{array}{l}\text { (a) Monovalent } \\
\text { ion }\end{array}$ & $\begin{array}{c}\beta \text {-Galactosidase } \\
\text { activity }(\%)\end{array}$ & $\begin{array}{l}(b) \text { Divalent } \\
\text { ion }\end{array}$ & $\begin{array}{c}\beta \text {-Galactosidase } \\
\text { activity }(\%)\end{array}$ \\
\hline Standard assay & 100 & $\mathrm{Mg}^{2+}$ & 100 \\
No additions & 0 & $\mathrm{No}$ additions $^{2+}$ & 36 \\
$\mathrm{Li}^{+}$ & 0 & $\mathrm{Mn}^{2+}$ & 89 \\
$\mathrm{Na}^{+}$ & 0 & $\mathrm{Ca}^{2+}$ & 61 \\
$\mathrm{~K}^{+}$ & 44 & $\mathrm{Ba}^{2+}$ & 36 \\
$\mathrm{Cs}^{+}$ & 0 & $\mathrm{Zn}^{2+}$ & 0 \\
$\mathrm{Rb}^{+}$ & 15 & $\mathrm{Cu}^{2+}$ & 0 \\
$\mathrm{NH}_{4}^{+}$ & 0 & & \\
Tris/HCl & 0 & & \\
\hline \hline
\end{tabular}

Table 4. Kinetic constants for the $\beta$-galactosidase and the $\beta$-glycosidase

\begin{tabular}{lcccccc}
\hline & \multicolumn{3}{c}{$\beta$-Galactosidase } & & \multicolumn{2}{c}{$\beta$-Glycosidase } \\
\cline { 2 - 4 } Substrate & Lactose & PNPGal & ONPGal & & Lactose & PNPGal \\
\hline$K_{\mathrm{m}}(\mathrm{mM})$ & 20 & 0.75 & 0.75 & & $5 \cdot 1$ & $2 \cdot 3$ \\
$k_{\text {cat }}\left(\mathrm{s}^{-1}\right)$ & 400 & 340 & 400 & & 50 & 30 \\
\hline \hline
\end{tabular}

respectively) the $\beta$-glycosidase has a fourfold higher affinity for this substrate.

The $\beta$-glycosidase exhibited Michaelis-Menten kinetics with PNPGal, but the double reciprocal plot with PNPGlu was non-linear, and hence no kinetic constants were obtained with this substrate.

\section{Substrate specificities of the two enzymes}

The $\beta$-galactosidase was highly specific for lactose (Table 5). Lactulose (4-O- $\beta$-D-galactopyranosyl-D-fructofuranose) was hydrolysed at a much slower rate. Of the nitrophenyl substrates, only ONPGal and PNPGal were hydrolysed by this enzyme (Table 5).

The $\beta$-glycosidase had a much wider substrate specificity. It hydrolysed lactose efficiently, and all the disaccharides of the formula $n-O$ - $(\beta$-D-glucopyranosyl (-)-D-glucopyranoside, where $n=2,3,4,6$ in order of decreasing reactivity. Indeed, at the same molar concentrations, sophorose, the $\beta-1,2$ disaccharide, was a much better substrate than lactose. The enzyme also hydro- 
Table 5. Substrate specificities of the two enzymes

$\beta$-Galactosidase and the $\beta$-glycosidase were measured with the substrates listed under standard conditions. Activities are expressed as $\mu \mathrm{mol}$ (ONP, PNP, glucose or fructose) $\mathrm{min}^{-1} \mathrm{mg}^{-1}$ (2-nitrophenol $\varepsilon=45001 \mathrm{~mol}^{-1} \mathrm{~cm}^{-1}$ ). No activity was detected with PNP- $\beta$-D-mannopyranoside, PNP- $\alpha$-D-mannopyranoside, PNP- $\alpha$-D-glucopyranoside or PNP- $\alpha$-D-galactopyranoside (both enzymes), sucrose or maltose ( $\beta$-glycosidase), and ONP-1-thiogalactopyranoside ( $\beta$-galactosidase). The results are the means of at least duplicate determinations.

\begin{tabular}{lccc}
\hline \hline \multicolumn{1}{c}{ Substrate } & $\begin{array}{c}\text { Substrate } \\
\text { concn } \\
(\mathrm{mM})\end{array}$ & $\begin{array}{c}\beta \text {-Galactosidase } \\
\text { activity } \\
\left(\mu \mathrm{mol} \mathrm{min}^{-1} \mathrm{mg}^{-1}\right)\end{array}$ & $\begin{array}{c}\beta \text {-Glycosidase } \\
\text { activity } \\
\left(\mu \mathrm{mol} \mathrm{min}^{-1} \mathrm{mg}^{-1}\right)\end{array}$ \\
\hline PNPGal & $2 \cdot 2$ & 118 & 17 \\
PNPGlu & $2 \cdot 2$ & 0 & 24 \\
ONPGal & $2 \cdot 2$ & 157 & 17 \\
Lactose & 50 & 125 & 44 \\
Lactose & $0 \cdot 5$ & ND & $4 \cdot 7$ \\
Lactulose & 80 & 16 & $3 \cdot 1$ \\
Cellobiose & 10 & 0 & 31 \\
Laminaribiose & $0 \cdot 5$ & ND & 34 \\
Laminaritriose & $0 \cdot 5$ & ND & 17 \\
Laminaritetraose & $0 \cdot 5$ & ND & $2 \cdot 3$ \\
Laminaripentaose & $0 \cdot 5$ & ND & $0 \cdot 9$ \\
Gentiobiose & 4 & ND & $0 \cdot 7$ \\
Sophorose & 0.5 & ND & 36 \\
\hline \hline
\end{tabular}

ND, Not determined.

lysed oligomers of the $\beta-1,3$ series, and the reactivity decreased as the chain was increased from biose to pentaose. Of the nitrophenyl $\beta$-glycosides tested, only ONPGal, PNPGal and PNPGlu were hydrolysed.

\section{Expression of $\beta$-galactosidase and $\beta$-glycosidase}

Experiments were done to determine the relative activities of the two enzymes during growth in different media, and to identify specific inducers for each enzyme. Two simple assay systems were used specifically to measure each enzyme in cell-free extracts. The combined activity of both enzymes was measured with PNPGal in the standard $\beta$-galactosidase assay. The $\beta$-glycosidase was measured with PNPGal in an assay system without $\mathrm{MgSO}_{4}$ but containing $5 \mathrm{~mm}$-EDTA to abolish the $\beta$-galactosidase activity. $\beta$-Galactosidase activity was calculated as the difference between the two assays. Fig. 2 shows the expression of the two enzymes during growth in lactose medium. The enzyme activities increased in parallel from the onset of growth. The $\beta$-galactosidase activity persisted into the late exponential phase, but the $\beta$-glycosidase activity decreased rapidly after the midexponential phase. The maximum activity for each enzyme coincided with the maximum growth rate.

Cell-free extracts were prepared from cells grown in a medium containing $0.15 \%$ yeast extract plus $0.1 \%$ casein

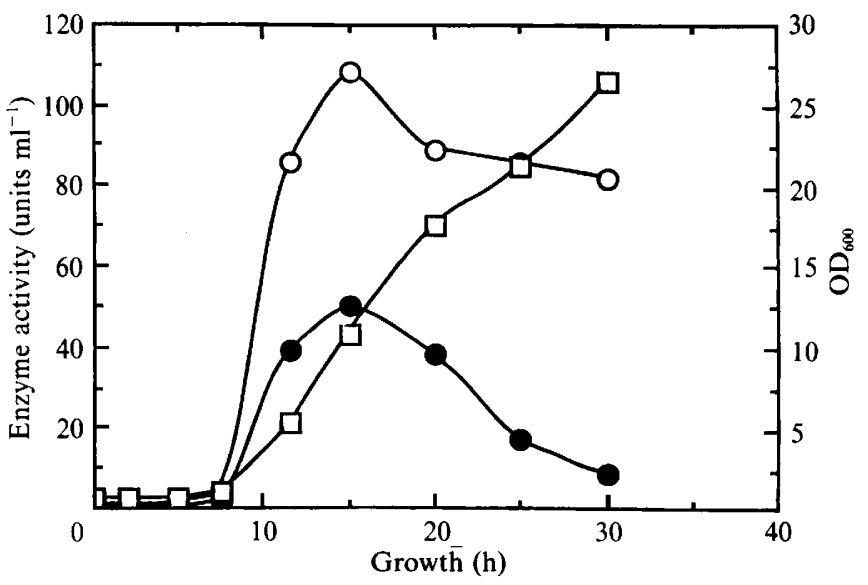

Fig. 2. Production of $\beta$-galactosidase and $\beta$-glycosidase during growth. A culture $(400 \mathrm{ml})$ containing $0.1 \%$ casein acid hydrolysate, $0.15 \%$ yeast extract and $5 \%$ lactose was measured for growth at $600 \mathrm{~nm}(\square)$. Cell extracts were prepared at various times and assayed for $\beta$-glycosidase ( $\bullet$ ) and $\beta$-galactosidase $(O)$ as described in the text. Enzyme activity is expressed as units (ml culture) ${ }^{-1}$.

\section{Table 6. Induction of $\beta$-galactosidase and $\beta$-glycosidase}

Cells grown in a medium containing $0.1 \%$ casein acid hydrolysate, $0.15 \%$ yeast extract and $2 \%$ peptone were harvested at $18 \mathrm{~h}$ and used to inoculate flasks containing nitrogen-free Wickerham's salts with trace elements (Wickerham, 1946) and sugar at $20 \mathrm{mM}$, except for lactose plus glucose, where the concentrations were 20 and $10 \mathrm{~mm}$, respectively. After $4 \mathrm{~h}$ the cells were harvested and cell-free extracts were assayed for activity towards PNPGal $(2.2 \mathrm{~mm})$ in $20 \mathrm{~mm}$-potassium phosphate, $\mathrm{pH} 7$, containing $1.1 \mathrm{~mm}-\mathrm{MgSO}_{4}$ or $20 \mathrm{~mm}$-potassium phosphate, $\mathrm{pH} 7$, containing 5 mM-EDTA. Activity was calculated as described in the text. The extracts were also assayed with PNPGlu. The $\beta$-galactosidase, $\beta$-glycosidase and PNPGlu activities in cell-free extracts from uninduced cells were $0.5-0.9,<0.1$ and $0.8-1.1 \mu \mathrm{mol}$ $(\mathrm{ml} \text { culture })^{-1}\left(\mathrm{OD}_{600} \text { unit }\right)^{-1}$, respectively. Cultures were grown in duplicate on each sugar, and the cell-free extracts from each culture were assayed in duplicate.

\begin{tabular}{lccc}
\hline \hline \multirow{2}{*}{ Sugar } & \multicolumn{3}{c}{ Enzyme activity $\left[\mu \mathrm{mol} \mathrm{ml}{ }^{-1}\left(\mathrm{OD}_{600} \text { unit }\right)^{-1}\right]$} \\
\cline { 2 - 4 } & $\beta$-Galactosidase & $\beta$-Glycosidase & PNPGlu \\
\hline Lactose & $4 \cdot 8$ & $7 \cdot 5$ & 14 \\
Lactose plus glucose & $1 \cdot 6$ & $3 \cdot 3$ & $6 \cdot 4$ \\
Lactulose & $4 \cdot 8$ & $3 \cdot 8$ & $\mathrm{ND}$ \\
Cellobiose & $0 \cdot 2$ & $2 \cdot 4$ & $5 \cdot 6$ \\
Galactose & $4 \cdot 1$ & $4 \cdot 0$ & $\mathrm{ND}$ \\
Lactobionic acid & $2 \cdot 3$ & $0 \cdot 2$ & $\mathrm{ND}$ \\
IPTG & $1 \cdot 1$ & $0 \cdot 0$ & $0 \cdot 2$ \\
\hline \hline
\end{tabular}

ND, Not determined.

hydrolysate and a carbon source $(5 \%, \mathrm{w} / \mathrm{v})$. These media gave rapid growth, but there was a 2 to $3 \mathrm{~h}$ lag phase before the enzyme activities increased. A trace of $\beta$-galactosidase activity was detected in cells grown with glucose. There was significant activity in the cells grown on glycerol, sorbitol and peptone $[1.2$ to $1.9 \mu \mathrm{mol}$ 
Table 7. Properties of lactose hydrolases from micro-organisms

\begin{tabular}{|c|c|c|c|c|c|}
\hline & \multirow[b]{2}{*}{ E. coli* } & \multirow[b]{2}{*}{ K. lactis $†$} & \multicolumn{2}{|c|}{ T. cutaneum } & \multirow[b]{2}{*}{ S. singularis $\ddagger$} \\
\hline & & & (1) & (2) & \\
\hline$M_{\mathrm{r}}$ & 116000 & 135000 & 120000 & 52000 & 140000 \\
\hline Substrates & Lactose & Lactose & Lactose & Lactose and cellobiose & Lactose and cellobiose \\
\hline Type of enzyme & $\beta$-Galactosidase & $\beta$-Galactosidase & $\beta$-Galactosidase & $\beta$-Glycosidase & $\beta$-Glycosidase \\
\hline Monovalent metal ion requirement & + & + & + & None & ND \\
\hline Divalent metal ion requirement & + & + & + & None & None \\
\hline pH optimum & $7 \cdot 0$ & $7 \cdot 25$ & $6 \cdot 5-7 \cdot 0$ & $6 \cdot 0-7 \cdot 0$ & $3 \cdot 9-4 \cdot 0$ \\
\hline
\end{tabular}

ND, Not determined.

* Wallenfels \& Weil (1972); Cohn \& Monod (1951).

$\dagger$ Dickson et al. (1979).

‡ Blakely \& MacKenzie (1969).

$\left.(\mathrm{ml} \text { culture })^{-1}\left(\mathrm{OD}_{600} \text { unit }\right)^{-1}\right]$, and a sixfold greater activity in lactose-grown cells. In contrast, only a trace of $\beta$-glycosidase activity was present in cells grown on each of these carbon sources except lactose $[2.9 \mu \mathrm{mol}$ $\left.(\mathrm{ml} \text { culture })^{-1}\left(\mathrm{OD}_{600} \text { unit }\right)^{-1}\right]$.

Enzyme production was measured in cells incubated in a minimal medium consisting of nitrogen-free Wickerham's salts and various carbon sources. Growth was limited, but there was no lag phase in the enzyme production. As shown in Table 6, the two enzyme activities increased four- to sevenfold with lactose, lactulose and galactose with respect to the starter culture. When 10 mM-glucose was included in the medium with lactose, the $\beta$-galactosidase and the $\beta$-glycosidase activities were decreased to $33 \%$ and $44 \%$ respectively of those observed with lactose alone. Lactobionic acid (4- $O$ - $\beta$-D-galactopyranosyl $\mathrm{D}$-gluconic acid) produced a significant increase in the $\beta$-galactosidase activity, but not the $\beta$-glycosidase, whereas cellobiose produced a significant increase in the $\beta$-glycosidase alone. IPTG had no effect on the activities of either the $\beta$-galactosidase or the $\beta$-glycosidase.

\section{Discussion}

The conversion of whey-lactose to lipid by $T$. cutaneum is of current interest because it could be the basis of an industrial process (Verwoert et al., 1989). The metabolism underlying the production of lipid by $T$. cutaneum has been studied in detail (Holdsworth et al., 1988) but the initial steps in lactose metabolism have not been investigated. The present study has shown that $T$. cutaneum has two lactose hydrolases, a $\beta$-galactosidase $\left(M_{\mathrm{r}} 120000\right)$ and a $\beta$-glycosidase $\left(M_{\mathrm{r}} 52000\right)$. N-terminal amino acid sequence analyses (30 residues) of the two enzymes were quite different (data not shown) and these showed no homologies with any published sequences.
The sequence analyses confirmed that each preparation consisted of one polypeptide.

The properties of several lactose hydrolases from micro-organisms are summarized in Table 7 . The $T$. cutaneum $\beta$-galactosidase is similar to the $\beta$-galactosidases from $E$. coli and $K$. lactis, but it requires $\mathrm{K}^{+}$or $\mathrm{Rb}^{+}$for activity and stability, whereas the enzymes from the other two organisms are activated by either $\mathrm{Na}^{+}$or $\mathrm{K}^{+}$. The enzyme from Kluyveromyces fragilis also specifically requires $\mathrm{K}^{+}$for stability (Mahoney \& Whitaker, 1977).

The $\beta$-glycosidase has a wider substrate specificity than the $\beta$-galactosidase and it hydrolyses glucosides including cellobiose, and galactosides, but not PNP- $\beta$-Dmannopyranoside, gentiobiose or sucrose. Sucrose is invariably hydrolysed by highly specific $\beta$-D-fructofuranosidases (Goldstein \& Lampen, 1975). Cellobiose hydrolysis is usually ascribed to $\beta$-glucosidases (Sanyal $e t$ al., 1988; Bronnenmeier \& Staudenbauer, 1988), but as the name suggests, these enzymes are specific for substrates in which glucose is joined by a $\beta$-link to another sugar or a nitrophenyl group. Both enzymes from T. cutaneum exhibited Michaelis-Menten kinetics with $\beta$-galactosides but the double reciprocal plot for the $\beta$-glycosidase with PNPGlu curved downwards. This type of plot is usually indicative of cooperativity or substrate activation, but other complexities also generate non-linear plots (Dixon \& Webb, 1979). The kinetics of the $\beta$-glycosidase require a more detailed study.

By exploiting the differing metal ion requirements and substrate specificities of the $\beta$-galactosidase and the $\beta$-glycosidase, each enzyme activity can be separately measured in crude extracts. When cultures were grown in lactose, both PNPGal- and PNPGlu-hydrolysing activities were expressed. With EDTA added to the assay system to eliminate the $\beta$-galactosidase activity, the ratio of PNPGal/PNPGlu activity in extracts from cells grown on different carbon sources ranged from 
$1: 1 \cdot 8$ (lactose) to $1: 2 \cdot 3$ (cellobiose), whereas the ratio for the purified $\beta$-glycosidase was $1: 1 \cdot 4$. This suggests that other enzymes in crude extracts hydrolyse PNPGlu. $\beta$-Glycosidase activity in cell extracts was therefore measured with PNPGal in the presence of EDTA.

Many of the $\beta$-glucosidases in bacteria and fungi are part of a cellulose-degrading system. Few yeasts, however, are able to hydrolyse cellulose, but many still possess $\beta$-glucosidases. These enzymes may be present to hydrolyse cellobiose that has been produced by the actions of other organisms (Leclerc et al., 1987), but they are undoubtedly able to hydrolyse other $\beta$-glucosides. $T$. cutaneum grows well on cellobiose, and the $\beta$-glycosidase is induced by this substrate. Our data strongly suggest that this enzyme also contributes to lactose hydrolysis, along with the $\beta$-galactosidase. The presence of two distinct lactose-hydrolysing enzymes in the same organism is unusual, and presumably confers some advantage.

Mörtberg \& Neujahr (1986) have carried out extensive studies with a yeast isolated from soil near a paper mill, and identified as $T$. cutaneum. This organism is, however, clearly different from the $T$. cutaneum used in the present study; the yeast studied by Mörtberg \& Neujahr (1986) produced an exocellular $\beta$-galactosidase, but both of the enzymes from our strain of $T$. cutaneum are intracellular.

$\beta$-Glucosidases have been purified from several yeasts including Saccharomyces cerevisiae (Inamdar \& Kaplan, 1966), Candida molischiana (Gondé et al., 1985) and Candida pelliculosa (Kohchi et al., 1985). These enzymes characteristically have native $M_{\mathrm{r}}$ values in the range 80000 to 500000 , and are oligomeric. Most are active in the presence of EDTA, have $\mathrm{pH}$ optima ranging from 4.5 to 7, and hydrolyse cellobiose and PNPGlu, but not lactose (Leclerc et al., 1987). The T. cutaneum $\beta$-glycosidase shares several of these properties ( $\mathrm{pH}$ optimum, activity in the presence of EDTA, and activity towards PNPGlu and cellobiose), but it has a lower $M_{\mathrm{r}}$. It is also capable of hydrolysing lactose. Hydrolases with activity towards cellobiose and lactose have been purified from snail gut extract (Got \& Marnay, 1968) and bacteria (Patchett et al., 1987; Takase \& Horikoshi, 1988). We have found only one report of an enzyme with this specificity in yeast. Blakely \& MacKenzie (1969) reported the characterization of a $\beta$-glucosidase from Sporobolomyces singularis that hydrolysed lactose and cellobiose. This enzyme has similar ionic requirements to the $\beta$-glycosidase characterized in this study, but the $M_{\mathrm{r}}$ $(140000)$ and the $\mathrm{pH}$ optimum (4-0) were different. It would be of interest to investigate the uncharacterized lactose hydrolases in other yeasts and fungi that grow on this disaccharide.
This work was supported by a grant from the Department of Scientific and Industrial Research, New Zealand. M.W. was the recipient of a Postgraduate Scholarship from the University of Otago, New Zealand.

\section{References}

BARNETT, J. A. (1981). The utilization of disaccharides and some other sugars by yeasts. Advances in Carbohydrate Chemistry and Biochemistry 39, 347-404.

Blakely, J. A. \& MacKenzie, S. L. (1969). Purification and properties of a $\beta$-hexosidase from Sporobolomyces singularis. Canadian Journal of Biochemistry 47, 1021-1025.

Bronnenmeier, K. \& Staudenbauer, W. L. (1988). Purification and properties of an extracellular $\beta$-glucosidase from the cellulolytic thermophile Clostridium stercorarium. Applied Microbiology and Biotechnology 28, 380-386.

BRUSS, M. L. \& BLACK, A. L. (1978). Enzymatic microdetermination of glycogen. Analytical Biochemistry 84, 309-312.

CoHn, M. \& Monod, J. (1951). Purification et propriétés de la $\beta$-galactosidase (lactase) d'Escherichia coli. Biochimica et Biophysica Acta 7, 153-174.

Dickson, R. C., Dickson, L. R. \& Markin, J. S. (1979). Purification and properties of an inducible $\beta$-galactosidase isolated from the yeast Kluyveromyces lactis. Journal of Bacteriology 137, 51-61.

Dixon, M. \& WEBB, E. C. (1979). Enzyme inhibition and activation. In Enzymes, 3rd edn, pp. 332-467. London: Longman.

GoldsteIN, A. \& LAMPEN, J. O. (1975). $\beta$-D-Fructofuranoside fructohydrolase from yeast. Methods in Enzymology 42C, pp. 504-511.

Gondé, P., Ratomahenina, R., Arnaud, A. \& Galzy, P. (1985). Purification and properties of the exocellular $\beta$-glucosidase of Candida molischiana (Zikos) Meyer and Yarrow capable of hydrolyzing soluble cellodextrins. Canadian Journal of Biochemistry and Cell Biology 63, 1160-1166.

GoT, R. \& MARNAY, A. (1968). Isolement, purification et quelques caractéristiques physicochimiques de deux $\beta$-hexosidases du sue digestif d'Helix pomatia. European Journal of Biochemistry 4, 240-246.

Holdsworth, J. E., Veenhuis, M. \& RatledGe, C. (1988). Enzyme activities in oleaginous yeasts accumulating and utilizing exogenous or endogenous lipids. Journal of General Microbiology 134, 2907-2915.

InAMDaR, A. N. \& Kaplan, J. G. (1966). Purification and properties of an inducible $\beta$-glucosidase of baker's yeast. Canadian Journal of Biochemistry 44, 1099-1108.

Kohchi, C., Hayashi, M. \& Nagai, S. (1985). Purification and properties of $\beta$-glucosidase from Candida pelliculosa var. acetaetherius. Agricultural and Biological Chemistry 49, 779-784.

LAEMmLI, U. K. \& FAVRe, M. (1973). Maturation of the head of bacteriophage T4. Journal of Molecular Biology 80, 575-599.

LeClerc, M., Arnaud, A., Ratomahenina, R. \& Galzy, P. (1987). Yeast $\beta$-glucosidases. Biotechnology and Genetic Engineering Reviews 5, 269-295.

MAHONEY, R. \& Whitaker, J. R. (1977). Stability and enzymic properties of $\beta$-galactosidase from Kluyveromyces fragilis. Journal of Food Biochemistry 1, 327-350.

Matsudaira, P. T. \& BURGess, D. R. (1978). SDS microslab linear gradient polyacrylamide gel electrophoresis. Analytical Biochemistry 87, 386-396.

Moon, N. J., Hammond, E. G. \& Glatz, B. A. (1978). Conversion of cheese whey and whey permeate to oil and single-cell protein. Journal of Dairy Science 61, 1537-1547.

MoRRISEY, J. H. (1981). Silver stain for proteins in polyacrylamide gels: a modified procedure with enhanced uniform sensitivity. Analytical Biochemistry 117, 307-310.

MÖRTBERG, M. \& NeUJAHR, H. Y. (1986). Transport and hydrolysis of disaccharides by Trichosporon cutaneum. Journal of Bacteriology 168, 734-738. 
Patchett, M. L., Daniel, R. M. \& Morgan, H. W. (1987). Purification and properties of a stable $\beta$-glucosidase from an extremely thermophilic anaerobic bacterium. Biochemical Journal 243, 779-787.

PETERSON, G. L. (1977). A simplification of the protein assay method of Lowry et al. which is more generally applicable. Analytical Biochemistry 87, 386-396.

Sanyal, A., Kundu, S., Dube, R. K. \& Dipak, K. (1988). Extracellular enzyme system of Aspergillus japonicus. 2. Purification and characterization of an inducible extracellular $\beta$-glucosidase. Enzyme and Microbial Technology 10, 91-99.

STURGEON, R. J. (1980). Enzymic determination of D-glucose, D-fructose and D-mannose. Methods in Carbohydrate Chemistry 8, 135-137.

TAKase, M. \& Horikoshi, K. (1988). A thermostable $\beta$-glucosidase isolated from a bacterial species of the genus Thermus. Applied Microbiology and Biotechnology 29, 55-60.
Uwajima, T., Yagi, Y. \& Terada, O. (1972). Purification, crystallization, and some properties of $\beta$-galactosidase from Saccharomyces fragilis. Agricultural and Biological Chemistry 36, 570-577.

Verwoert, I. I. G. S., Ykema, A., ValkenburG, J. A. C., Verbree, E. C., NiJKamp, H. J. J. \& SMIT, H. (1989). Modification of the fattyacid composition in lipids of the oleaginous yeast Apiotricum curvatum by intraspecific spheroplast fusion. Applied Microbiology and Biotechnology 32, 327-333.

WALLENFELS, K. \& WeIL, R. (1972). $\beta$-Galactosidase. In The Enzymes, vol. 7, pp. 618-665. Edited by P. D. Boyer. New York: Academic Press.

WiCKERHAM, L. J. (1946). A critical review of the nitrogen assimilation tests commonly used in the classification of yeasts. Journal of Bacteriology 52, 293-301. 